[DOI: 10.24214/jecet.A.9.1.19705.]

Juurnal of Enviranmental Science, Computer Science and Engineering \& Technology

An International Peer Review E-3 Journal of Sciences and Technology

Available online at www.jecet.org

Section A: Environmental Science

Research Article

\title{
A Case Study to Assess the Groundwater Quality for Potability of a Tropical River Basin, Bharathapuzha in South India
}

\author{
M. Dhanusree* and Dr.G Bhaskaran** \\ * Research Scholar, Center for Water Resource Management, University of Madras, India \\ ** Associate Professor and Head, Center for Water Resource Management, University of Madras, \\ India
}

Received: 20 January 2020; Revised: 05 January 2020; Accepted: 15 February 2020

\begin{abstract}
Ground water is one of the important natural resource which is essential for the sustenance of life on the Earth. The adequate supply of water is important for the drinking, irrigation, domestic and other industrial needs. Water quality can be thought of as a measure of the suitability of water for a particular use based on selected physical, chemical, and biological characteristics. The Bharathapuzha River is the second longest $(209 \mathrm{~km})$ and largest (annual discharge $3.94 \mathrm{~km}^{3}$ ) among the west flowing perennial rivers (41 in number) in the state of Kerala of India. The river is the life line water resource for more than 4.5 million people residing in four administrative districts, namely Malappuram, Trissur and Palakkad districts of Kerala, and Coimbatore district of Tamil Nadu. The study has been carried for two time periods ie for the year 2007 and 2017.The study was mainly based on secondary data. Parameters like PH, Electrical Conductivity, Calcium, Magnesium, Sodium, Potassium Chloride Fluoride and Nitrate were taken for the study. For water quality BIS (Bureau of Indian Standards) norms were followed. ArcGIS 9.3 software was used for mapping spatial data and mathematical calculations were done in MS Excel. While comparing quality of water for two time periods it can be noted that the areas coming under vulnerable category is increasing. The water quality of the western parts of the basin is in permissible limit. Most of the areas in southern and eastern parts of the basin lies in desirable and vulnerable category.
\end{abstract}


Keywords: Water quality evaluation, BIS Standards

\section{INTRODUCTION}

Ground water is one of the important natural resource which is essential for the sustenance of life on the Earth. The adequate supply of water is important for the drinking, irrigation, domestic and other industrial needs. Groundwater occurs in the pore spaces of sediments and rocks. The occurrence and distribution of groundwater is confined to certain geological structures and formations ${ }^{[1]}$.Thus, proper exploration technique must be employed to solve the problems of exploitation and management of groundwater

Water quality can be thought of as a measure of the suitability of water for a particular use based on selected physical, chemical, and biological characteristics. To determine water quality, scientist's first measure and analyze characteristics of the water such as temperature dissolved mineral content, and number of bacteria. ${ }^{[2]}$ Selected characteristics are then compared to numeric standards and guidelines to decide if the water is suitable for a particular use.

For the Nation as a whole, the chemical and biological character of ground water is acceptable for most uses. The quality of ground water in some parts of the country, particularly shallow ground water, is changing as a result of human activities. Ground water is less susceptible to bacterial pollution than surface water because the soil and rocks through which ground water flows screen out most of the bacteria. Bacteria, however, occasionally find their way into ground water, sometimes in dangerously high concentrations. But freedom from bacterial pollution alone does not mean that the water is fit to drink. Many unseen dissolved mineral and organic constituents are present in ground water in various concentrations. Most are harmless or even beneficial; though occurring infrequently, others are harmful, and a few may be highly toxic. The groundwater quality of a region can be influenced by anthropogenic or by natural conditions. The land use /land cover, Geological structures are some of the factors which influence the groundwater Quality of the region ${ }^{[3]}$.

Natural resources and environmental concerns, including Groundwater have benefited greatly from the use of GIS. Typical examples of GIS applications in groundwater studies are site suitability analyses, Managing site inventory data, estimating vulnerability of groundwater to pollution potential from non point source of pollution, Modeling of Groundwater Movement ,modeling solute transport and leaching, and integrating groundwater quality assessment models with spatial data to create spatial decision support systems ${ }^{[4]}$.The present study aims to find out the spatial distribution of groundwater quality and its change over time of Bharathapuzha river basin using geospatial techniques.

\section{STUDY AREA}

The Bharathapuzha River is the second longest (209 km) and largest (annual discharge $3.94 \mathrm{~km}^{3}$ ) among the west flowing perennial rivers (41 in number) in the state of Kerala of India. The river basin covers $1 / 9$ of the total geographical area of the state. The flow regime of the river covers highlands $(>76 \mathrm{~m}$ above MSL), midlands ( $8-76 \mathrm{~m}$ above MSL) and the low lands ( $<8 \mathrm{~m}$ above MSL). The river has a well-developed flood plain and fluvial terrace of recent origin. The river is the life line water resource for more than 4.5 million people residing in four administrative districts, namely Malappuram, Trissur and Palakkad districts of Kerala, and Coimbatore district of Tamil Nadu. There are eleven dams and irrigation projects in the river basin catering to 493,064 ha area under cultivation. (Water resource information System of India). In recent years, the basin is facing severe dearth of water and drought like situations, perhaps for the increasing anthropogenic pressures and development works that grossly 
neglect the hydrologic flow regime of the basin. Unsustainable exploitation of water, in stream sand mining and clay mining for brick kilns are among the striking threats to flow of the river.

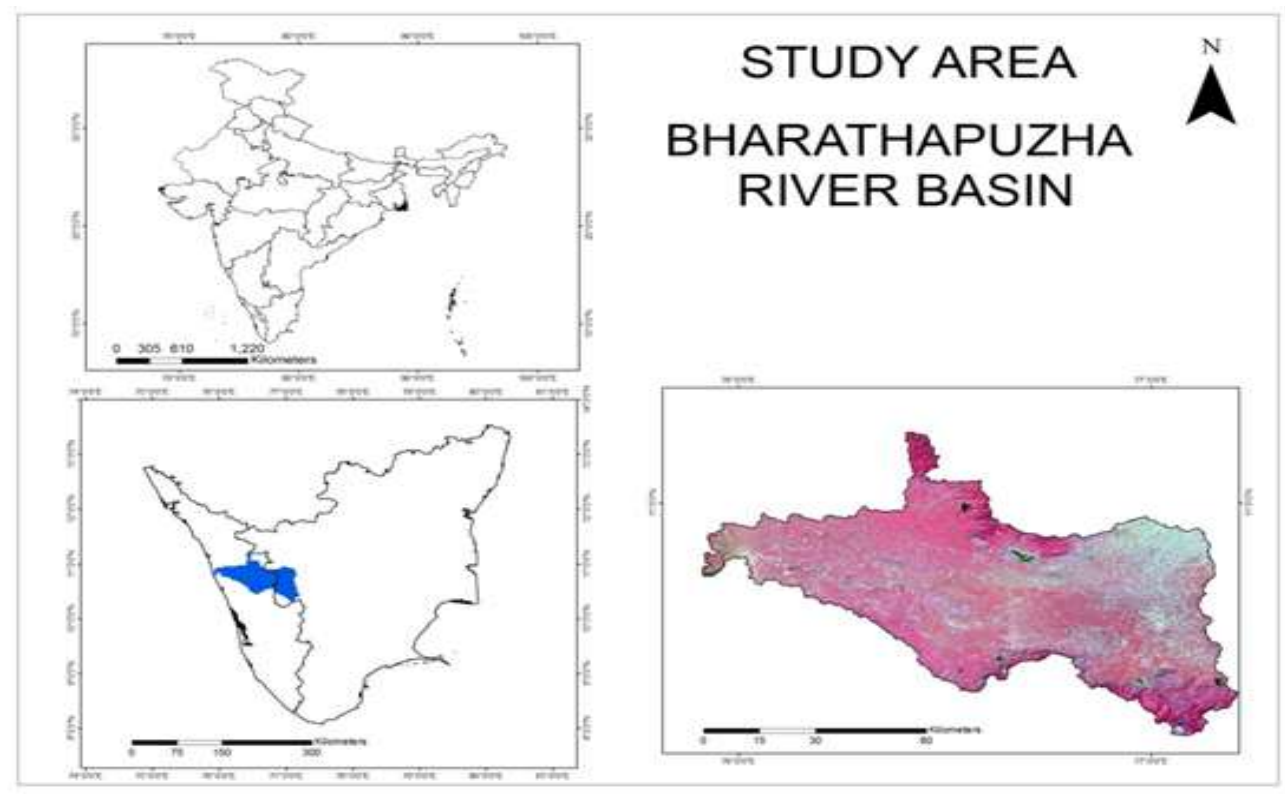

Fig. 1: Study area map

\section{DATA AND METHODS}

The study has been carried for the two time period ie for the year 2007 and 2017.The study was mainly based on secondary data. Parameters like PH, Electrical Conductivity, Calcium, Magnesium, Sodium, Potassium Chloride Fluoride and Nitrate were taken for the study. All the data pertaining to ground water were collected from CGWB Central Ground Water Board.

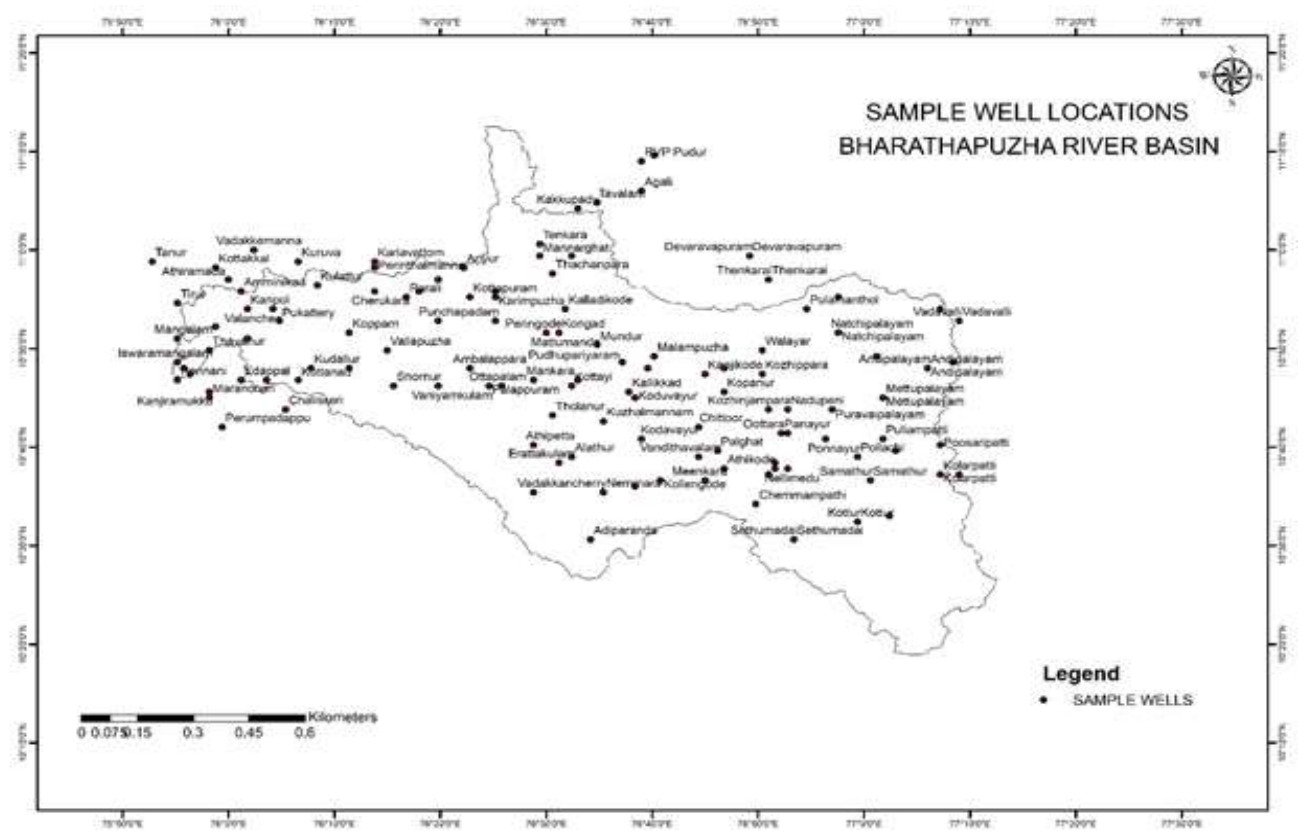

Fig. 2 : Sample well locations 
Kerala region, Trivandrum and Central Ground Water Board. Tamilnadu region, Chennai. For assessing groundwater quality, 80 sample wells were selected throughout the study area. For water quality BIS ${ }^{5}$ norms were followed. ArcGIS 9.3 software was used for mapping spatial data and mathematical calculations were done in MS Excel.

\section{RESULTS AND DISCUSSIONS}

4.1. Fluoride: Fluoride is the thirteenth abundant element in the crust of the earth and is mostly in the insoluble form, hence will be present in ground water only when conditions favor their dissolution. Though many sources contribute Fluoride the predominant one is Fluoride rich rocks and soils. Fluorides are present in fluorspar in sedimentary rocks (limestone, sandstone) and as crinoline in igneous rocks. The common Fluoride minerals are Fluorite $\left(\mathrm{CaF}_{2}\right)$ Apatite $\left\{(\mathrm{CaClF}, \mathrm{OH})\left(\mathrm{PO}_{4}\right)_{3}\right\}$ and Hornblende. (CGWB)

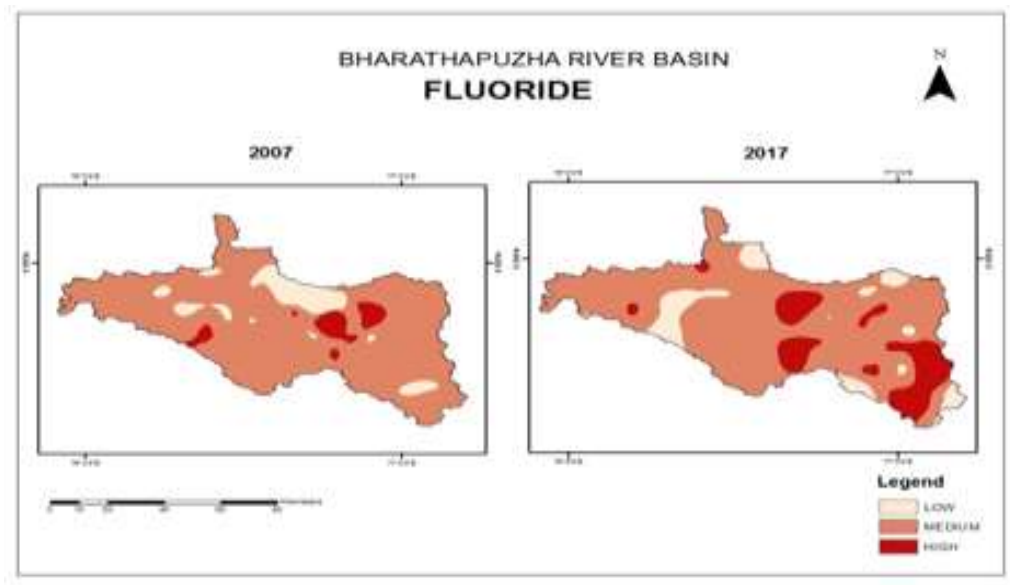

Fig. 3: Distribution of Flouride

Fluoride is an essential element in the growth of human body but in the same time its presence in excess amount are physiologically harmful in many ways. As in the case of iron, the presence of fluoride in traditional water bodies especially open wells will be more during summer months. The less dilution and lowering the water level are main reasons. The lowering the water allows more retention time for the water in the soil thereby dissolving more fluoride from the crust of the earth ${ }^{6}$.

The fluoride values in the basin ranges from 0.5 to $7.3 \mathrm{mg} / \mathrm{L}$.General distribution of fluoride shows that the Eastern parts of the basin along with northern and southern parts have higher concentrations of Fluoride. Attapadi records the highest amount of fluoride ie 7.3 in the study area. Other places of high Fluoride(>1.5) content is Kanjkode, Walayar, Kozippara, Kozhinjmapara, Kollengode, Nellimedu, Palghat, Chemmanampathy, Puliampetty, Kovilpalayam, Chittur \& Samthur. Western parts of the basin are having comparatively less fluoride content. The variations of Fluoride depends on the amount of soluble fluoride in source rocks, rock-water interactions with rocks and soil temperature, rainfall, oxidation-reduction process $^{[7]}$.

4.2. Potential of Hydrogen: The $\mathrm{pH}$ values in the area ranges from 3.6 to $12.5 \mathrm{mg} / \mathrm{l}$. The spatial distribution of fluoride content does not show a special trend throughout the basin. When compared to the year 2007 the year 2017 is showing a light increase in the value of $\mathrm{pH}$. The water is more acidic in 
the areas of Ettimada, Navakkarai, Malampuzha, Kollengode, Kanjikode , Kopanur, Chittor, Pudunagaram, Ootara, Pudunagaram, Nellimedu, Chemmanampathy, Gopalapuram, Ambarampalayam, Chokkanur and Kozhiapara. According to BIS standers the normal range of $\mathrm{pH}$ ranges between 6.5 to 8.5

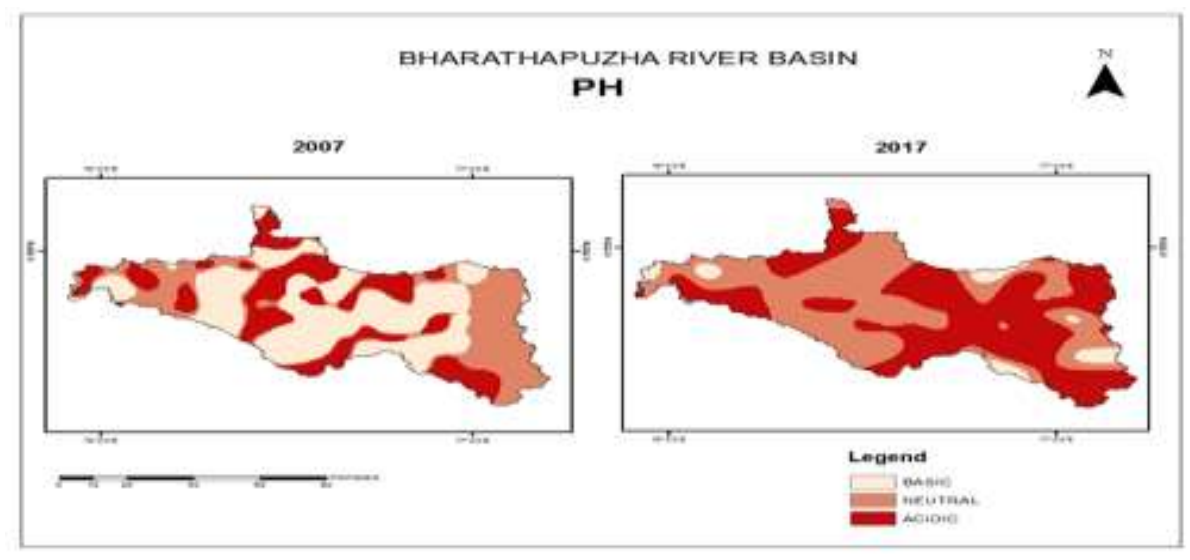

Fig. 4 : Distribution of $\mathrm{pH}$

Table 1: BIS standards of different quality parametres

\begin{tabular}{|c|c|c|c|}
\hline $\begin{array}{l}\text { Substance or } \\
\text { Characteristics }\end{array}$ & $\begin{array}{l}\text { Requirement } \\
\text { (Acceptable } \\
\text { Limit) }\end{array}$ & $\begin{array}{l}\text { Undesirable effect outside the } \\
\text { acceptable limit }\end{array}$ & $\begin{array}{l}\text { Permissible limit in the } \\
\text { absence of alternate } \\
\text { source }\end{array}$ \\
\hline $\mathrm{pH}$ value & $6.5-8.5$ & $\begin{array}{l}\text { Beyond this range the water will } \\
\text { affect the mucous membrane and/or } \\
\text { water supply system. }\end{array}$ & No Relaxation \\
\hline $\begin{array}{l}\text { Electrical conductivity } \\
(\mu \mathrm{mhos} / \mathrm{cm})\end{array}$ & 500 & & 1000 \\
\hline $\begin{array}{l}\text { Magnesium (as Mg), } \\
\text { mg/l, Max }\end{array}$ & 30 & $\begin{array}{l}\text { Encrustation in water supply } \\
\text { structure and adverse effects on } \\
\text { domestic use. }\end{array}$ & No Relaxation \\
\hline $\begin{array}{l}\text { Potassium (as k)mg/l } \\
\text { Max }\end{array}$ & 10 & No Relaxation & \\
\hline $\begin{array}{l}\text { Calcium (as Ca), mg/l, } \\
\text { Max }\end{array}$ & 75 & $\begin{array}{l}\text { Encrustation in water supply } \\
\text { structure and adverse effects on } \\
\text { domestic use. }\end{array}$ & 200 \\
\hline $\begin{array}{l}\text { Sodium (as Na), mg/l, } \\
\text { Max }\end{array}$ & 200 & No Relaxation & \\
\hline $\begin{array}{l}\text { Nitrate (as NO3) mg/l, } \\
\text { Max }\end{array}$ & 45 & $\begin{array}{l}\text { Beyond this methaemoglobinamia } \\
\text { takes place/ may be indicative of } \\
\text { pollution }\end{array}$ & No relaxation \\
\hline Chlorides (as mg/l, Max & 250 & $\begin{array}{l}\text { Beyond this limit taste corrosion and } \\
\text { palatability are affected. }\end{array}$ & 1000 \\
\hline $\begin{array}{l}\text { Fluoride (as F) mg/l, } \\
\text { Max }\end{array}$ & 1 & $\begin{array}{l}\text { Fluoride may be kept as low as } \\
\text { possible. High fluoride may cause } \\
\text { fluorosis. }\end{array}$ & 1.5 \\
\hline
\end{tabular}


4.3.Calcium:Calcium occurs in water naturally. One of the main reasons for the abundance of calcium in water is its natural occurrence in earth's crust. The values of calcium in the basin range from 9.5 to $180 \mathrm{mg} / \mathrm{l}$. All the samples are observed to be within the limit of BIS standards, except only one sample which is recorded at Kattampatty.

4.4. Electrical Conductivity: Electrical conductance (EC), or conductivity, is the ability of a substance to conduct an electric current. Specific electrical conductance is the conductance of a unit length and unit cross section at a specified temperature. Conductivity is a measure of how well water can pass an electrical current ${ }^{3}$. It is an indirect measure of the presence of inorganic dissolved solids such as chloride, nitrate, sulphate, phosphate, sodium, magnesium, calcium, iron and aluminium. The presence of these substances increases the conductivity of a body of water.

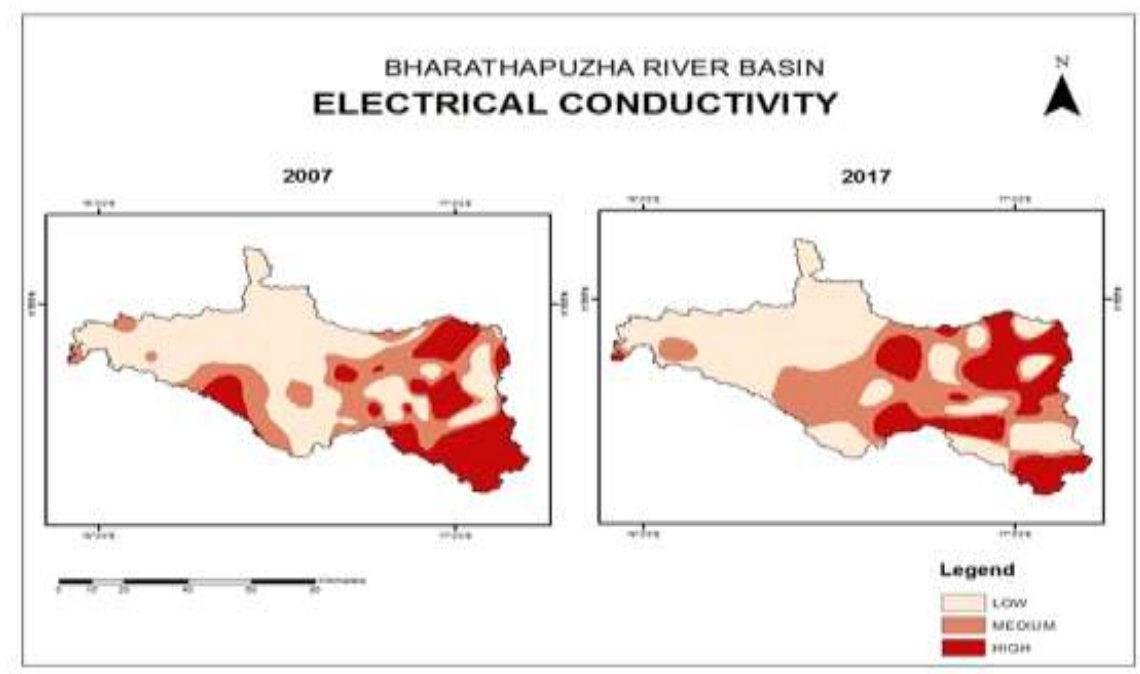

Fig. 5 : Distribution of EC

In the study area the EC value shows a very wide range of distribution and extends from 52 to 8882 .The distribution of EC is high in eastern parts of the district. The western parts of the basin are having comparatively less EC values. Places like Ettimadai. Kozhinjapara, Kollengode, Nellimedu, Ootara, Chittor, Chokkanur, Meenkara, Gopalapuram, Pudhunagaram, Puliampatti, Pollachi, Samathur, Kinathukadavu and Pudupariyaram are some of the places where the EC values are more than the permissible limit. According to BIS standards, the desirable limit for EC is $500 \mathrm{micromhos} / \mathrm{cm}$. The maximum permissible limit is $1000 \mathrm{micromhos} / \mathrm{cm}$.

4.5. Magnesium: Magnesium is common in natural waters as $\mathrm{Mg}^{2}$ and along with calcium is a main contributor to water hardness. Magnesium arises principally from the weathering of rocks containing ferro Magnesium minerals and from some carbonate rocks. Magnesium occurs in many organo metallic compounds and in organic matter, since it is an essential element for living organisams. Natural levels of Magnesium in fresh water may range from 1-100 mg depending on rock types within the catchment [8].

4.6 Sodium: All natural waters contain some sodium since its salts are highly water soluble and it is one of the most abundant elements on earth. It is found in the ionic form $\mathrm{Na}+$ in plant and animal matter, since it is an essential element for living organisms. Increased levels in the surface waters may arise from sewage and industrial effluents and from the use of salts on roads to control snow and ice. The latter source can also contribute to increased sodium levels in ground waters. In coastal areas sea 
water intrusion can also result in higher levels of sodium. Sodium is commonly measured where the water is to be used for drinking or agricultural purposes, particularly irrigation. Elevated sodium in certain soil types can degrade soil structure there by restricting water movement and effecting plant growth.

According to BIS standards of water quality, any water where the level of sodium is below $200 \mathrm{mg}$ is considered as good .The sodium values in the basin ranges between 7.7 to $532 \mathrm{mg} / \mathrm{l}$. The eastern part of the district is recorded with high sodium values. Places like Gopalapuram, Kollengode Kanjikode, Vadachittur, Chittur, Ootara are the places where the value of sodium goes beyond $200 \mathrm{mg}$.

4.7. Pottasium: Potassium is found in low concentration in natural waters since rock which contain potassium are relatively resistant to weathering. However potassium salts are widely used in industry and in fertilizer for agriculture and enter fresh waters with industrial discharges and run off from agricultural land ${ }^{[9]}$.

Potassium permanganate may be used in the drinking-water treatment process. Resulting levels of potassium in drinking-water are relatively low compared with levels resulting from the use of water softeners using potassium chloride. Where potassium permanganate is used in water treatment, concentrations of added potassium can be up to a maximum of $10 \mathrm{mg} / \mathrm{l}$, but normally concentrations would be less than this(WHO). Adverse health effects due to potassium consumption from drinkingwater are unlikely to occur in healthy individuals. Potassium intoxication by ingestion is rare, because potassium is rapidly excreted in the absence of pre-existing kidney damage and because large single doses usually induce vomiting ${ }^{[10]} \mathrm{BIS}$ standards suggests that the desirable limit for potassium in ground water is $10 \mathrm{mg} .100 \mathrm{mg}$ is the maximum permissible limit for $\mathrm{K}$. The value $\mathrm{K}$ in the basin ranges from 0.5 to $120 \mathrm{mg} / \mathrm{l}$. The values of $\mathrm{K}$ exceed the permissible limits only in some places like Gopalapuram, Kanjikode and Kattampatty.

4.8. Nitrate:Nitrate ion $\left(\mathrm{NO}_{3}\right)$ is the common form of combined nitrogen found in natural waters. It may be bio chemically reduced to nitrate $\left(\mathrm{NO}_{2}\right)$ by denitrification process usually under anaerobic condition. Natural sources of nitrate to surface water include igneous rocks, land drainage and plant and animal debris (WHO). Natural levels which seldom exceeds $0.1 \mathrm{mg}$ may be enhanced by municipal and industrial waste water.

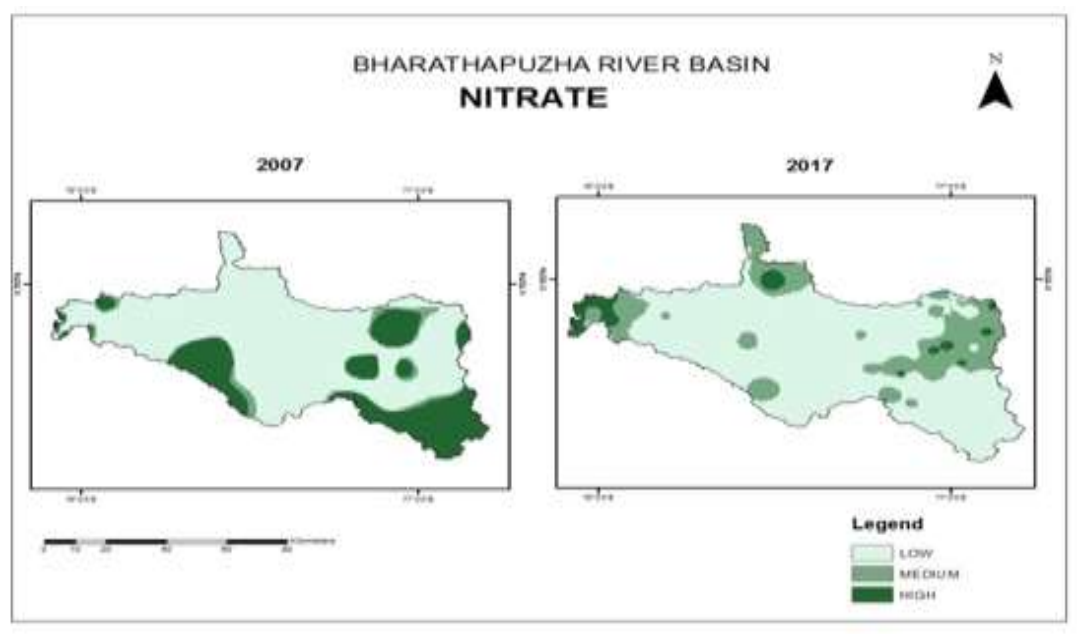

Fig. 6 : Distribution of Nitrate 
The Nitrate in the basin ranges between 0.5 to $152 \mathrm{mg} / \mathrm{l}$. In most of the places the amount of nitrate was in acceptable limit below $45 \mathrm{mg}$ and some places like Kanjikode, Chavadiyur, Mannargahat, Meenakshipuram and Malappuram is showing the nitrate values more than the permissible limit. While comparing the change in spatial distribution of nitrate for two time periods, it is noted that in the year 2017 most of the places in the basin comes under permissible limit.

4.9. Chloride:Chlorides are widely distributed in nature as salts of sodium $(\mathrm{NaCl})$, potassium $(\mathrm{KCl})$, and calcium $\left(\mathrm{CaCl}_{2}\right)$. Most chlorine occurs as chloride in solution. It enters surface waters with the atmospheric deposition of oceanic aerosols, with the weathering of some sedimentary rocks, mostly rock salt deposits, and from industrial and sewage effluents, and agricultural and road run off. The salting of roads during winter periods can contribute significantly to chloride increases in ground water. High concentration of chloride can make waters unpalatable and therefore, unfit for drinking. Higher concentration can occur near sewage and other waste outlets, irrigation drains, salt water intrusions in arid areas. The value of chloride in basin the ranges between 5.6 to $870 \mathrm{mg} / \mathrm{l}$. All the samples in the basin is showing that the value of chloride is under permissible limit.

4.10. Water Quality Evaluation: Finally by evaluating the groundwater quality of the Bharathapuzha river we can classify the basin into three categories like areas where the water quality contamination is Permissible, Desirable and Vulnerable.

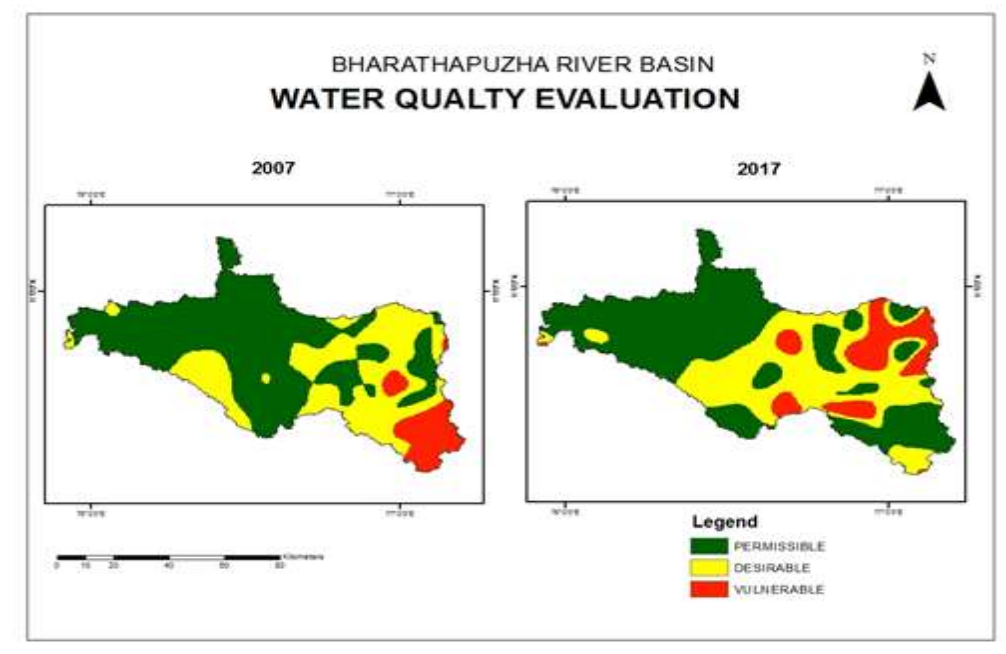

Fig. 7 :Water quality map

While comparing quality of water for two time periods it can be noted that the areas coming under vulnerable category is increasing. The water quality of the western parts of the basin is in permissible limit. Most of the areas in southern and eastern parts of the basin lies in Desirable and Vulnerable category. Places like Kanjikode, Chittur, Kollengode, Chemmanampathy, Ettimada, Chokkanur, Kinathukadavu are some of the places where the groundwater quality goes beyond vulnerable level. The Eastern part of the basin is facing a severe water crisis.

\section{CONCLUSION}

From the study it is noted that the eastern parts of the basin is facing a severe water quality issues while water quality of western parts of the basin is safe. The over explotation of groundwater resources is one the major reason for poor ground water quality. So proper management of water resources need to be 
carried out in the area to reduce the crisis. Groundwater is one of the precious resources which nature has gifted us. It is one of the purest sources of water. Not only humans, there are other living things who has the right to use this resource. We humans do not have the right to exploit as well as contaminate this resource. It is high time we wake up and realize the importance of the present situation.

\section{REFERENCE}

1. K. Sundar Kumar P. Sundar Kumar, M.J. Ratnakanth Babu and Ch. Hanumantha Rao, Assessment andMapping of Ground Water Quality Using Geographical Information System, International Journal of EngineeringScience and Technology,2010, 2, 1, 6035-6046.

2. M.C. Manjunatha and H.T. Basavarajappa, Spatio-temporal variation in Groundwater quality analysis on Chitradurga district, Karnataka, India using Geo-informatics technique, Journal of International Academic Research for Multidisciplinary,2015, 3, 11, 164-179.

3. CGWB District handbook of Palakkad, Thrissur, Malappuram and Coimbatore, 2015.

4. Bilgehan Nas and Ali Berktay, Groundwater quality mapping In Urban Groundwater using GIS, Environ Moni Assess,2010, pp 215 to227

5. BIS , Indian standard specification for drinking water, Bureau of Indian Standard, publication no. IS:10501, New Delhi, 1991,India, Pp: 1-10.

6. WHO, Guidelines For drinking water Quality,3 rd edition World health organization,2004.

7. Mangukiya Rupal, Battacharaya Tanushree and Chakraborty Sukalyan, Quality Characterization of groundwater using water quality index in Surat City, Gujarat, India, 2012, Internation Research journal of environment science,2012,1(4) 14-23

8. D.Chapman and V. Kimstach, Selection of Water Quality Variable. W of Biota, Sediments and Water Quality Assessments: A Guide to of the Use of Biota. In: Sediments and Water in Environment Monitoring, 2nd Edition, Chapmam Edition, E\& FN Spon, London1996., 59-126.

9. K.V. Sasthri, P.Rathee, Physio chemical and microbiological characteristics of water of village Kanneli,Haryana, Proc.Academia, Environmenatl Biology 1988,17,103-108

10. R.E.Gosselin, R.P.Smith, H.C. Hodge, Clinical toxicology of commercial products,. 5th ed. Baltimore, MD: Williams \& Wilkens, 1984,112, 185-193.

\section{* Corresponding Author: M. Dhanusree,}

Research Scholar, Center for Water Resource Management, University of Madras,India

Date of publication on line 15.02.2020 